\title{
Decomposition of the Theil Index in Inequality Analyses in Yogyakarta Indonesia
}

\author{
Oki Wijaya ${ }^{1,}{ }^{*}$, Deni Aditya Susanto ${ }^{2,3}$, Triatmi Heruwarsi ${ }^{4}$, Sri Giyanti ${ }^{4}$, Nik Rahlia Nik \\ Ibrahim $^{5}$ \\ ${ }^{1}$ Department of Agribusiness, Faculty of Agriculture, Universitas Muhammadiyah Yogyakarta, \\ Indonesia \\ ${ }^{2}$ Creavill Consultant, Indonesia \\ ${ }^{3}$ Department of Economics, Faculty of Economics and Business, Universitas Gadjah Mada, \\ Indonesia \\ ${ }^{4}$ Regional Planning and Development Agency, Daerah Istimewa Yogyakarta, Indonesia \\ ${ }^{5}$ Universiti Teknikal Malaysia Malaka, Malaysia
}

\begin{abstract}
Yogyakarta is Indonesia's province with the highest inequality at the Gini ratio of 0.417 . This research brings into focus inequality in Yogyakarta and inequality distribution by regions and the economic sectors. Methodologically, this research uses the descriptive quantitative analysis model to spell out inequality distribution. The analysis units are regions and the economic sectors at provincial and district/city levels. The parameter used is the Theil index with the approach of inequality of between-region, between-sector, within-region, and within-sector. The results exhibit that at the provincial level, Yogyakarta has a Theil index of 0.686 . The region with the highest inequality is Bantul (0.737), whereas other areas come with severe inequality $(>0.5)$. In regard to between-region inequality, the highest inequality distribution is between Sleman and Kulon Progo and Gunungkidul. At district/city levels, the highest inequality is identified in the agricultural, trade, and industrial sectors. Finally, the highest inequality distribution is between the construction sector and the agricultural, trade, and industrial sectors.
\end{abstract}

\section{Introduction}

\subsection{Background}

A classic discussion of efficiency and equality remains popular. In his famous work, "Equality and Efficiency: The Big Trade off, [1], in 1975, wrote a synthesis that inequality and efficiency will be always a tradeoff in the process of economic development. He added

\footnotetext{
* Corresponding author: okiwijaya@umy.ac.id
} 
that the tradeoff is divided into several main factors, i.e., the domination of financial and capital sources, power to intervene in the market, equality of opportunity and income, and endowment of human resources. This tradeoff issue is happening globally, including in developed countries. And yet, the developed countries are able to reduce the issue through fiscal policies, e.g., social security and production efficiency.

[2] disclosed a reciprocal relationship between inequality and social outcomes. This reciprocal relationship is the product of inequality causality. Inequality, as a historical heritage, will affect social outcomes (health, criminality, and others), and social outcomes will deteriorate inequality. For instance, in Latin America (Costa Rica) in 1981, a causality impact was identified to occur in inequality intervened by economic policies. However, the policies breed equal social outcomes, which exacerbate inequality, at other times. Income inequality also impacts public access to public policies and fiscal incentives.

Indonesia indicated slowly decreased inequality by 38.2 points in 2020 [3]. In spite of the decrease, the public perception of inequality remains high. The World Bank's survey in 2015 manifested that $51 \%$ of the community perceive inequality in the last five years, whereas $40.6 \%$ perceive that Indonesia is suffering from severe inequality. The survey continued to dividing community groups and collecting the data of community income in the last five years. $24 \%$ of those belonging to the poorest group experience an extreme income decrease (Graph 1). On the other hand, Graph 1 likewise points out that $56 \%$ of those belonging to the wealthiest group has a significant income increase in the last five years. The data from the 2018 Global Wealth Report asserted this and addressed the share of Indonesia's national income, that $1 \%$ of the wealthiest people control $46.6 \%$ of the total income in Indonesia [4].

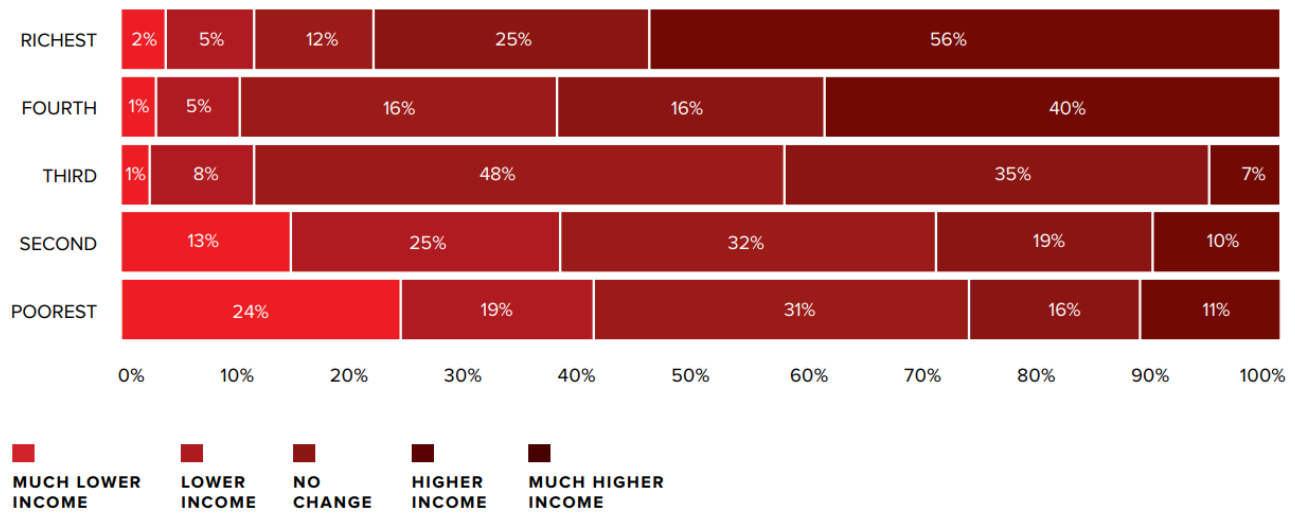

Fig. 1. The Income Level of Each Quantile Changed in the Last 5 Years of Indonesia Source: [15]

Furthermore, as regards inequality in Indonesia, Statistics Indonesia in Yogyakarta (2021), through the data from the National Socioeconomic Survey (SUSENAS), showed that $48.73 \%$ of the poor community works in the agricultural sector. Poverty in the agricultural sector is the source of between-sector inequality because of the sector's slower growth relative to that of other sectors [5]. The growth of the agricultural sector is below the last 20 -year economic growth, namely between $0.3-0.4 \%$ per year [6]. Meanwhile, other sectors' growth surpasses the economic growth. For example, the construction sector has a growth of $8.2 \%$, the trade sector presents a growth of $7.2 \%$, and the financial and transportation sectors show off the growth of $7.99 \%$ and $16 \%$, respectively. The sectoral growth rate brings about between-sector inequality in Indonesia.

Poverty in the agricultural sector is derived foremost from different complex problems, which are price fluctuation due to supply-demand issues, profitability management, capital 
size and technology, production input, and commerce problems [7-9]. Indonesia is an agricultural country which unfortunately starts being disoriented in terms of agricultural policies. An example of the disorientation is counterproductive food import policies to efforts to elevate agricultural productivity. Another example is the fulfillment of agricultural production input through subsidy cannot cover all needs in the agricultural sector, especially small farmers' needs [10-11]. In addition, discriminative institutions burden small farmers, making the farmers unable to access agricultural inputs, inter alia, fertilizer and seeds. Lastly, the supply chain in the agricultural trade system is another thread confronted by farmers as the margin of the farm is determined by how effectively the supply chain works [12-13]

Sectoral inequality topics are increasingly popular in recent times. Inequality is often measured from the difference in income per capita based on regional boundaries, such as using the Gini index and the Williamson index. This research, which discusses sectoral inequality, confers an answer to the issue of "which sector is considered the most unequal of all sectors". Meanwhile, the previous research argued that agriculture is the most unequal sector if analyzed in regions and between sectors. An inequality analysis aims to deliver a description of performance equality and economic impacts. The result of the analysis is foreseeable to be one of the policy considerations for stakeholders concerned [14]. Policies building on sectoral inequality considerations allow a more effective and efficient policy intervention. The policies can be developed with a more detailed analysis of program implementation.

This research sets an aim to investigate between-sector inequality in an area and to identify between-region/sector inequality. This research is carried out in five regions (district/city) in Yogyakarta. The first analysis, covering the analyses of within-region inequality, within-sector inequality, between-region inequality, and between-sector inequality, is conducted at the provincial level. The analyses aim to disentangle inequality distribution based on regional and sectoral characteristics. The second group of analyses is made up of the analyses of within-sector inequality and between-sector inequality. Analyses at district/city levels aim to elaborate inequality distribution within sectors and between sectors in a district/city. All analyses will present a comprehensive identification and description of inequality at provincial and regional levels, bringing on a tiered policy recommendation preference. Yogyakarta is selected as the research area owing to its highest inequality rate $(0.434)$ across the country. Inequality in Yogyakarta is higher than that in underdeveloped areas in the eastern part of Indonesia. These inequality analyses contribute to policy-making concerning priority sectors and strategic issues in Yogyakarta, which is regarded as a developed city and the center of education and tourism.

\subsection{Literature Review}

\section{Theory of Inequality}

"Inequality is a broader concept than poverty in that it is defined over the entire population, and does not only focus on the poor" [15]. According to his explanation, inequality analyses goes beyond the study of poverty. It gives an idea of income distibution and population influence. Inequality is a difference in income distribution that occurs along with economic development activities and policies. Furthermore, inequality occurs within the framework which has a relatively similar background, namely the basis of social structures, including development equity policies that are biased, so that they can only be accessed by priority groups.

Inequality is a parameter of social justice in order to emphasize the efficiency in equity of economic development policies. Eventhough, economic efficiency often brings 
inequality in the distribution of income among the community. Linear economic efficiency with inequality occurs due to access to economic policies. Furthermore, the lowest income group is unable to adopt and adapt to the economic efficiency development efforts. Moreover, believe that income inequality is caused by beneficial for growth and redistribution of taxes and transfer payments. Those public financial policies then create disincentives and inefficiencies. Finally, they concluded that economic efficiency and income distribution will always face a tradeoff. In other words, the higher and faster the efficiency, the less equal distribution will be, which will have an impact on income inequality.

In sectoral analyses, income inequality between multiple sectors occurs due to the policy priorities and mainstay sectors. The highest financial growth sectors are the priority for employment, such as the industrial, construction, financial services, and extraction sectors. Moreover, the more dominant uneducated workers, the more massive mobilization of sectoral worker will be. The occurrence of massive mobility of agricultural sector workers in developing countries towards the industrial, service, and extraction sectors due to the attraction of investment. Thus, income inequality occurs because of the concentration of economic activity and it increases by the disincentives of development policies.

Inequality has various measurement standards depending on the purpose of the analyses. The measure of inequality into 4 types, namely the Gini ratio and the Williams index, Theil's index, the indicator of the world bank, and the $\mathrm{L}$ index. The Gini ratio aims to measure the distribution of income in general and on average. Meanwhile, the World Bank indicator analyzes inequality based on the wealthiest 20 percent of income groups, 40 percent of the middle income, and 40 percent of the poorest. One of the analyses based on the World Bank indicator can be seen in graph 1. It describes the development of income in community group over the last 5 years.

Theil index or known as Theil Entropy is a measuring inequality approach with a mathematical model that can be developed based on the purpose of the analysis. Theil entropy in principle analyzes income per capita and its relation to the population among the regions being compared. Inequality measurements are as follow:

a. Gini Ratio

$$
\mathrm{GR}=1-\sum_{\mathrm{i}=1}^{\mathrm{n}} \mathrm{F}_{\mathrm{pi}}\left(\mathrm{F}_{\mathrm{ci}-1}+\mathrm{Y}_{\mathrm{ci}}\right)
$$

GR, Gini Ratio of Fpi, is the frequency of population in the $i$-th income/outcome class. Meanwhile, Fci is the cumulative frequency of total income/outcome in the $i$-th income/outcome class. FCi-1 is the cumulative frequency of total income/outcome in the (i1) income/outcome class.

b. Williamson Index

$$
I \mathrm{~W}=\frac{\sqrt{\sum\left(\mathrm{Y}_{\mathrm{i}}-\mathrm{Y}\right)^{2}\left(\frac{\mathrm{F}_{\mathrm{i}}}{\mathrm{n}}\right)}}{\mathrm{Y}}
$$

The Williamson Index (IW) is obtained by calculating the root of the sigma operation, that is Gross Regional Domestic Product (GRDP) per capita of the study area (Yi) minus GRDP per capita of the area above it (Y). Then, it is raised to the power of two, by multiplying the result of the population of the study area (Fi) by the population of the area above it (n). The last, the result of this root is divided by the GRDP per capita of the region above it (Y).

c. Theil Index

$$
\mathrm{IT}=\sum\left(\frac{\mathrm{y}_{\mathrm{i}}}{\mathrm{y}_{\mathrm{j}}}\right) \log \left(\frac{\frac{\mathrm{y}_{\mathrm{i}}}{\mathrm{y}_{\mathrm{j}}}}{\frac{\mathrm{n}_{\mathrm{i}}}{n_{\mathrm{j}}}}\right)
$$


Theil Index (IT) in one region is calculated based on the sigma quotient of the GRDP per capita of the region above it (Yi) with the smaller GRDP per capita of the region (Yj). Then, the sigma result is multiplied by the log of the quotient $\mathrm{Yi}$ by $\mathrm{Yj}$ divided by the population of the region above it $\left(\mathrm{n}_{\mathrm{i}}\right)$ by the number of inhabitants of the smaller region $\left(\mathrm{n}_{\mathrm{j}}\right)$.

\section{Methodology}

\subsection{Data}

The research data is a secondary data in the same period (cross section data). The study area is Yogyakarta Province and its district/city consisting of the City of Yogyakarta, Sleman, Bantul, Kulon Progo, and Gunungkidul. The secondary data analyzed is the GRDP value based on the business sector in 2019 and the population. The data was obtained from the website of the Central Bureau of Statistics Yogyakarta and processed using Microsoft Excel.

\subsection{Models \& Research Approach}

This research is a descriptive quantitative model which analyzes quantitative data with a statistical approach in describing the results. Descriptive quantitative models provide the easier information of analysis results and the elaboration of various theories related to research findings. This research aims to explain the existing phenomena in numeric to know the characteristic of individual or group. This study also assessed the nature of the conditions. The purpose of this study is limited to describing the characteristics of something as it is.

\subsection{Method Analysis}

The method analysis used in this research is a descriptive statistical analysis with a descriptive approach. Statistical analysis is a technique for performing several statistical operations with the aim of quantifying data and applying statistical analysis. The analyzed quantitative data includes the descriptive data, such as surveys and observation data. Secondary data is processed by mathematical methods through a determined formula. In this study, mathematical analysis uses sigma and logarithmic calculations as well as the theil index calculation formula for both within and between inequality. The last is the descriptive approach. The author presents the calculation results into a visual display such as tables and graphs as well as narratives to explain causal phenomena.

\subsection{Design and Research Framework: Theil Analysis}

Theil analysis is able to describe the proportion of inequality causes and the types of inequality. Theil analysis can be decomposed as needed to get analysis deeply and to get several interconnected frameworks. Theil analysis in this study consists of several analyses to reduce the inequality analysis that occurs in the study area of Yogyakarta. The theory of inequality distribution fundamentally must be able to describe: "how unequal the distribution is" and explore the question "why such inequality exists". Drawing conclusions using the Theil Index parameter 0 to 1 , which is closer to 1 , it means that inequality is getting higher. The distribution of inequality can be analyzed based on several boundaries, economic sectors and regional boundaries. These two things are used to describe the 
distribution of inequality from various sides. This study describes inequality in several analyses.

\subsubsection{Theil Analysis of Province Level}

a. Within-Region Inequality

$$
\mathrm{WRI}_{\mathrm{PL}}=\sum\left(\frac{\mathrm{y}_{\mathrm{i}}}{\mathrm{y}_{\mathrm{j}}}\right) \log \left(\frac{\frac{\mathrm{y}_{\mathrm{i}}}{\mathrm{y}_{\mathrm{j}}}}{\frac{\mathrm{n}_{\mathrm{i}}}{\mathrm{n}_{\mathrm{j}}}}\right)
$$

Within-Region Inequality (WRI) is a theoretical analysis to measure inequality within a region. This analysis is divided into provincial and district/city levels. At the provincial level, WRI is calculated based on the sigma quotient of GRDP province per capita (Yi) with GRDP district/city per capita (Yj). Next, the sigma result is multiplied by the log of the quotient $\mathrm{Yi}$ by $\mathrm{Yj}$ divided by the number of population in the province (ni) and the number of population in the district/city (nj).

b. Within-Sector Inequality

$$
W S I_{P L}=\sum\left(\frac{y_{i}}{X_{i}}\right) \log \left(\frac{\frac{y_{i}}{X_{i}}}{\frac{n_{i}}{n X_{i}}}\right)
$$

Within-Sector Inequality (WSI) is a theoretical analysis to measure inequality in sectors at the provincial level. WSI is calculated based on the sigma quotient of GRDP province per capita (Yi) with GRDP sector i per capita (Xi). Then, the sigma result is multiplied by the $\log$ of the quotient of Yi by Xi divided by the total population in the province (ni) and the number of population in sector $\mathrm{i}(\mathrm{nXi})$.

c. Between-Region Inequality of Province Level

$$
B R I_{P L}=\left(\frac{X_{i}}{X_{j}}\right) \log \left(\frac{\frac{X_{i}}{X_{j}}}{\frac{n_{i}}{n_{j}}}\right)
$$

Between-Region Inequality (BRI) of Province Level is an analysis of inequality between regions (regencies/cities) within a province. This is used to determine the distribution of inequality between regencies/cities in Yogyakarta. The BRIPL is calculated by dividing the GRDP sector i per capita (Xi) with the GRDP sector $\mathrm{j}$ per capita $(\mathrm{Xj})$ multiplied by the logarithm of the GRDP district/city i per capita (Xi) with the GRDP district/city j per capita $(\mathrm{Xj})$ divided by the population in regency/city $\mathrm{i}(\mathrm{Ni})$ and divided by the total population in regency/city j $(\mathrm{Nj})$.

d. Between-Sector Inequality of Province Level

$$
B S I_{P L}=\left(\frac{X_{i}}{X_{j}}\right) \log \left(\frac{\frac{x_{i}}{X_{j}}}{\frac{n_{i}}{n_{j}}}\right)
$$

Between-Sector Inequality (BSI) of Province Level is an analysis of inequality between sectors at the provincial level. This is calculated to determine the distribution of inequality between sectors in Yogyakarta. This BSIPL is calculated by dividing the GRDP sector $\mathrm{i}$ per capita $(\mathrm{Xi})$ with the GRDP sector $\mathrm{j}$ per capita $(\mathrm{Xj})$ multiplied by the logarithm of the 
GRDP sector i per capita (Xi) divided by the total population of sector i (Ni) divided by the total population of sector $\mathrm{j}(\mathrm{Nj})$.

\subsubsection{Theil Analysis of County/City Level}

a. Within-Sector Inequality of County/City Level

$$
\mathrm{WSI}_{\mathrm{CL}}=\sum\left(\frac{\mathrm{y}_{\mathrm{i}}}{\mathrm{y}_{\mathrm{j}}}\right) \log \left(\frac{\frac{y_{\mathrm{i}}}{\frac{y}{\mathrm{j}}_{\mathrm{j}}}}{\frac{\mathrm{n}_{\mathrm{i}}}{n_{\mathrm{j}}}}\right)
$$

Within-Sector Inequality (WRI) is a theoretical analysis to measure inequality within a sector. WRICL is calculated based on the sigma quotient of GRDP district/city i per capita (Yi) with GRDP sector j per capita (Yj). Furthermore, the sigma result is multiplied by the $\log$ of the quotient of $\mathrm{Yi}$ with $\mathrm{Yj}$ divided by the total population in district/city $\mathrm{i}$ (ni) by the number of population of sector $\mathrm{j}$ in district/city (nj).

b. Between-Sector Inequality of County/City of County/City Level

$$
\operatorname{BSI}_{P L}=\left(\frac{X_{i}}{X_{j}}\right) \log \left(\frac{\frac{x_{i}}{x_{j}}}{\frac{n_{i}}{n_{j}}}\right)
$$

Between-Sector Inequality (BSI) of County/City Level is an analysis of inequality between sectors at the district/city level. This is used to determine the distribution of inequality between sectors in each district/city. This BSICL is calculated by dividing the GRDP sector i per capita $(\mathrm{Xi})$ with the GRDP sector $\mathrm{j}$ per capita $(\mathrm{Xj})$ multiplied by the logarithm of the GRDP sector i per capita (Xi) divided by the total population of sector $\mathrm{i}(\mathrm{Ni})$ divided by the total population of sector $\mathrm{j}(\mathrm{Nj})$.

\section{Result and Discussion}

\subsection{An Overview of The Study Area}

Yogyakarta is a province with special autonomy as one of the centers of culture and former state capital. The province has an area of $3,186 \mathrm{~km}^{2}$. Furthermore, it has four districts, i.e., Sleman, Bantul, Kulon Progo, and Gunungkidul, and one city, i.e., Yogyakarta, which is also the province capital [6]. The GRDP of Yogyakarta is dominated by the agricultural sector, which has the highest employment rate $(21.62 \%)$. The majority of traditional communities who live in rural areas work in the agricultural sector. Meanwhile, the trade sector in Yogyakarta hires 19.25\% of laborers (Table 1). The trade sector, as the impact of the tourism sector which is considered as the driving force of the economy of Yogyakarta, plays a critical role in employment.

Nonetheless, the sector with the highest employment rate only generates GRDP of less than half of the labor percentage. The agricultural sector, with an employment rate of $21.62 \%$, can only produce an $8.39 \%$ GRDP. The condition causes inequality by virtue of GRDP per capita. The evidence suggests that the agricultural and trade sectors are two sectors with the lowest GRDP per capita, i.e., 18.89 million and 20.54 million per year, respectively. Meanwhile, the real estate and public administration sectors achieve a GRDP per capita of 5.196 billion and 100 million per year, respectively. This dissimilarity signals great inequality between sectors at large.

Income inequality distribution in Yogyakarta is confirmed by the Gini ratio. In 20152020, inequality in Yogyakarta increased from 0.420 to 0.437 . Meanwhile, Indonesia had 
inequality decreased from 0.402 to 0.385 within the same period of years. Inequality in Yogyakarta is a fundamental issue which has been prevalent for years. The variable of human development index (HDI) significantly contributes to inequality in Yogyakarta. A dummy regression approach and figured out that an increase in HDI by $1 \%$ will suppress the Gini ratio by $9.53 \%$. Nevertheless, the government does not seek to enhance the HDI factors optimally, particularly the HDI factors of education, health, and economic (purchase power) access equality. Equality in access cannot take place in Yogyakarta for high education is only accessible for urban and immigrant communities.

Table 1. GRDP Value, GRDP Structure, Amount of Labor and Structure Labor in Special Region of Yogyakarta

\begin{tabular}{|l|r|r|r|r|r|}
\hline \multicolumn{1}{|c|}{ Sector } & \multicolumn{1}{|c|}{$\begin{array}{c}\text { GRDP(IDR } \\
\text { Million) }\end{array}$} & $\begin{array}{c}\text { Percent } \\
\text { age of } \\
\text { GRDP } \\
(\boldsymbol{\%})\end{array}$ & $\begin{array}{c}\text { GRDP } \\
\text { per } \\
\text { capita } \\
\text { (IDR } \\
\text { Million) }\end{array}$ & $\begin{array}{c}\text { Amount of } \\
\text { Labor }\end{array}$ & $\begin{array}{c}\text { Percent } \\
\text { age of } \\
\text { Labor } \\
(\%)\end{array}$ \\
\hline A. Agriculture & $8,526,740.30$ & 8.39 & 18.89 & 451,376 & 21.62 \\
\hline B. Mining & $508,376.00$ & 0.50 & 24.85 & 20,460 & 0.98 \\
\hline C. Industry & $2,623,614.40$ & 12.42 & 38.68 & 326,318 & 15.63 \\
\hline D. Electricity and Gas & $162,929.80$ & 0.16 & 60.03 & 2,714 & 0.13 \\
\hline $\begin{array}{l}\text { E. Water and sewage } \\
\text { treatment }\end{array}$ & $103,901.00$ & 0.10 & 82.94 & 1,253 & 0.06 \\
\hline F. Construction & $9,634,836.10$ & 9.48 & 68.47 & 140,716 & 6.74 \\
\hline G. Trade & $8,253,025.20$ & 8.12 & 20.54 & 401,896 & 19.25 \\
\hline H. Transportation & $4,383,207.20$ & 4.31 & 69.06 & 63,468 & 3.04 \\
\hline I. Accommodation & $8,489,705.70$ & 8.35 & 45.23 & 187,691 & 8.99 \\
\hline J. Communication & $13,998,335.90$ & 13.77 & 807.82 & 17,328 & 0.83 \\
\hline K. Finane & $3,763,896.10$ & 3.70 & 130.64 & 28,811 & 1.38 \\
\hline L. Real Estate & $7,594,529.50$ & 7.47 & $5,196.61$ & 1,461 & 0.07 \\
\hline M,N. Private Services & $1,041,993.50$ & 1.02 & 26.27 & 39,668 & 1.9 \\
\hline O. Public Adm. & $7,311,590.00$ & 7.19 & 100.35 & 72,863 & 3.49 \\
\hline P. Educational Services & $9,555,495.50$ & 9.40 & 67.31 & 141,968 & 6.8 \\
\hline Q. Health Services & $3,294,799.10$ & 3.24 & 68.61 & 48,019 & 2.3 \\
\hline R,S,T,U. Others Services & $2,432,624.90$ & 2.39 & 17.16 & 141,760 & 6.79 \\
\hline
\end{tabular}

Source: [3]

Table 2. Inequality by Gini Ratio in Indonesia and Yogyakarta

\begin{tabular}{|l|c|c|}
\hline Year & D.I. Yogyakarta & Indonesia \\
\hline 2015 & 0,420 & 0,402 \\
\hline 2016 & 0,425 & 0,394 \\
\hline 2017 & 0,440 & 0,391 \\
\hline 2018 & 0,422 & 0,384 \\
\hline 2019 & 0,428 & 0,380 \\
\hline 2020 & 0,437 & 0,385 \\
\hline
\end{tabular}

Source: [3]

Poverty is another problem in Yogyakarta. It comes even with a higher percentage than that of poverty across Indonesia. At the provincial level, in 2020, 12.28\% of the total communities in Yogyakarta were poor. The percentage decreased from 14.91\%, which was identified in 2015. Besides, income inequality distribution at district/city levels is great. In 2021, Kulon Progo and Gunungkidul demonstrated $18.01 \%$ and $17.07 \%$ poverty levels, respectively. Meanwhile, Sleman exhibited an $8.12 \%$ poverty level in the same year. Extreme inequality condition which happens in areas with relatively similar characteristics indicates extreme poverty with a higher percentage than $10 \%$ of the sample of the poor community. 
Table 3. Percentage of Poverty Indonesia and County/City of Special Region of Yogyakarta

\begin{tabular}{|l|c|l|r|r|r|r|}
\hline \multirow{2}{*}{ Region } & \multicolumn{7}{|c|}{ Percentage of Poverty } \\
\cline { 2 - 7 } & $\mathbf{2 0 1 5}$ & $\mathbf{2 0 1 6}$ & $\mathbf{2 0 1 7}$ & $\mathbf{2 0 1 8}$ & $\mathbf{2 0 1 9}$ & $\mathbf{2 0 2 0}$ \\
\hline Indonesia & 11.13 & 10.7 & 10.12 & 9.66 & 9.22 & 10.19 \\
\hline D.I. Yogyakarta Prov. & 14.91 & 13.34 & 13.02 & 12.13 & 11.7 & 12.28 \\
\hline Kulonprogo Regency & 21.4 & 20.3 & 20.03 & 18.3 & 17.39 & 18.01 \\
\hline Bantul Regency & 16.33 & 14.55 & 14.07 & 13.43 & 12.92 & 13.50 \\
\hline Gunungkidul Regency & 21.73 & 19.34 & 18.65 & 17.12 & 16.61 & 17.07 \\
\hline Sleman Regency & 9.46 & 8.21 & 8.13 & 7.65 & 7.41 & 8.12 \\
\hline Yogyakarta City & 8.75 & 7.7 & 7.64 & 6.98 & 6.84 & 7.27 \\
\hline
\end{tabular}

Source: [3]

\subsection{Theil Analysis of Province Level}

Income distribution inequality in Yogyakarta is a fundamental problem that needs to be handled seriously. This is related to the trend that increases continuously. This case makes the inequality more getting steeper. Gini ratio of 0.437 in 2020 as the example, the calculation of the theil index in Yogyakarta shows the same indication. In Table 4, the Theil Index in Yogyakarta is very high, it is 0.686 ( $>0.50$ middle limit). While at the district/city level, all regions have a theil index more than 0.50 , so they can be categorized as a high level. Moreover, the highest Theil Index is Bantul, 0.737 (Table 4). Furthermore, the second highest Theil Index is Kulon Progo (0.688). Sleman is in third position with a Theil Index of 0,537 and Gunungkidul is at the last position with the Theil Index 0,526.

Within-Region Inequality indicates an even distribution of income in a geographic area. Table 4 shows that Sleman has a quite high GRDP per capita although the inequality is also quite high. This result indicates a good productivity, so that the inequality becomes the next problem. Therefore, Gunungkidul has the lowest Theil Index in the region even though the GRDP per capita is the lowest. Thus, Gunungkidul can be classified as an area with equal distribution of poverty because of its low GRDP per capita. Meanwhile, Bantul is the area with the second highest GRDP but it has the highest Theil Index (0.737). Such conditions illustrate the extreme inequality of income distribution in the region.

Table 4. Within-Region Inequality of Special Region of Yogyakarta and County/City Level

\begin{tabular}{|l|r|r|r|r|}
\hline \multicolumn{1}{|c|}{ Region } & \multicolumn{1}{c|}{ GRDP } & \multicolumn{1}{c|}{ Labor } & GRDP Per Capita & Theil Index \\
\hline In Yogyakarta & $104,489,706,400,000$ & $2,381,874$ & $43,868,695$ & 0.686 \\
\hline Gunungkidul & $13,603,374,830,000$ & 511,469 & $26,596,683$ & 0.526 \\
\hline Kulon Progo & $8,772,582,560,000$ & 338,989 & $25,878,689$ & 0.688 \\
\hline Sleman & $35,289,808,400,000$ & 257.579 & $137,005.607$ & 0.537 \\
\hline Bantul & $19,154,769,070,000$ & 480,027 & $39,903,524$ & 0.737 \\
\hline
\end{tabular}

Table 5. Between-Region Inequality of Yogyakarta and County/City Level

\begin{tabular}{|l|r|r|r|r|r|}
\hline \multicolumn{1}{|c|}{ Region } & In Yogyakarta & Gunungkidul & Kulon Progo & Sleman & Bantul \\
\hline In Yogyakarta & 0 & 0.171 & 0.241 & 0.339 & 0.166 \\
\hline Gunungkidul & 0.171 & 0 & 0.039 & 0.491 & 0.051 \\
\hline Kulon Progo & 0.241 & 0.039 & 0 & 0.737 & 0.013 \\
\hline Sleman & 0.339 & 0.491 & 0.703 & 0 & 0.210 \\
\hline Bantul & 0.166 & 0.051 & 0.009 & 0.210 & 0 \\
\hline
\end{tabular}

The next analysis is Between-Region Inequality which describes the income distribution between the compared regions. Generally, the distribution of income between provinces and districts/cities is relatively equal, with the Theil Index around 0.16 to 0.33 . The highest Between-Region Inequality is in Sleman which is compared to other regions. 
Sleman has the highest GRDP per capita of 137 million per year. This makes a big range from other regions (Table 4). Furthermore, In Table 5, between-Region Inequality in Sleman is mainly in Kulon Progo Regency (0.703) and Gunungkidul Regency (0.491).

Table 6. Within-Sector Inequality of Yogyakarta

\begin{tabular}{|l|r|c|c|r|}
\hline \multicolumn{1}{|c|}{ Sector } & \multicolumn{1}{|c|}{ GRDP } & Labor & per capita & Theil Index \\
\hline Agriculture & $8,184,692,000,000$ & 650,397 & $12,584.155$ & 0.172 \\
\hline Trade & $8,643,437,900,000$ & 579,100 & $14,925,648$ & 0.988 \\
\hline Industry & $13,201,887,100,000$ & 470.199 & 28.077 .242 & 0.184 \\
\hline Services & $27,306,107,400,000$ & 477,419 & $57,195,292$ & 0.244 \\
\hline Construction & 18.920 .767 .500 .000 & 204.760 & $92,404,565$ & 0.674 \\
\hline
\end{tabular}

In the Within-Sector Inequality analysis, the agricultural sector Yogyakarta has an equal income distribution, though it is categorized as a low income (Table 6). Furthermore, the highest inequality sector is the trade sector with a Theil Index of 0.988 (close to 1). The trade sector inequality is a consequence of the central areas in tourism growth. It happened because the structure of trading companies and small traders are heterogeneous. Another high Theil Index in Table 6 is the construction sector with a value of 0.674 . The reason of this inequality is the high sectoral growth followed by the business development, while manual labors are more increasing due to the urbanization process.

Table 7 provides an analysis of Between-Sector Inequality at the level of Yogyakarta Province. Between-Sector Inequality Analysis presents the inequality between the industrial sector and the construction sector (0.666). Furthermore, the second largest Between-Sector Inequality is the agricultural sector with the construction sector (0.615). Basically, this inequality can be analyzed from the GRDP value per capita of the agricultural and the industrial sector with a big range from the construction sector. This happenned because of the high growth of the construction sector as an educational and tourism city. However, the agricultural sector grew sluggishly due to the problem of limited land and the conversion to real estate. Meanwhile, the industrial sector is fulfilled by unskilled laborers with low salary.

Table 7. Between-Sector Inequality of Yogyakarta

\begin{tabular}{|l|r|r|r|r|r|}
\hline \multicolumn{1}{|c|}{ Sector } & Agriculture & Trade & Industry & Services & Construction \\
\hline Agriculture & 0.000 & 0.034 & 0.251 & 0.548 & 0.615 \\
\hline Trade & 0.024 & 0.000 & 0.045 & 0.441 & 0.485 \\
\hline Industry & 0.051 & 0.045 & 0.000 & 0.148 & 0.666 \\
\hline Services & 0.548 & 0.441 & 0.148 & 0.000 & 0.023 \\
\hline Construction & 0.615 & 0.485 & 0.666 & 0.023 & 0.000 \\
\hline
\end{tabular}

\subsection{Theil Analysis of County/City Level}

In the previous section, Theil Analysis reviewed the inequality of income distribution at the provincial level both from the regional and sectoral side. In this section, Theil Analysis is more specific at the district/city level to provide information about the patterns and sources of inequality in each district/city.

The first is Gunungkidul, which is dominated by mountainous areas, plantations, and long beaches. Gunungkidul is a low-income area in Yogyakarta with a per capita income only 26 million per year (Table 4). The sector with the highest inequality in Gunungkidul is the trade sector (0.640). Meanwhile, the service sector is at the second rank with 0.599. An interesting analysis of Within-Sector Inequality in Gunungkidul is the construction and the agricultural sectors. The construction sector has an equal income distribution, the Theil Index is 0.172 . Besides, it also has a GRDP per capita around 149 million per year. 
Meanwhile, the agricultural sector has an equal income distribution of 0.224 with a sectoral income per capita of 8.9 million per year. It can be concluded that Gunungkidul has an equal low income distribution. This condition is caused by natural factors, education level, and land ownership.

Table 8. Within-Sector Inequality of Gunungkidul County

\begin{tabular}{|l|l|r|r|r|}
\hline \multicolumn{1}{|c|}{ Sector } & \multicolumn{1}{c|}{ GRDP } & \multicolumn{1}{c|}{ Labor } & \multicolumn{1}{c|}{ per capita } & Theil Index \\
\hline Agriculture & $2,753,512,590,000$ & 307,750 & $8,947,226$ & 0.224 \\
\hline Trade & $1,315,100.74$ million & 77,349 & $17,002,229$ & 0.640 \\
\hline Industry & $1,297,664,940,000$ & 45,810 & $28,326,999$ & 0.544 \\
\hline Services & $3,279,180,820,000$ & 68,010 & $48,215,804$ & 0.599 \\
\hline Construction & $1,873,705,470,000$ & 12,549 & $149,311.138$ & 0.172 \\
\hline
\end{tabular}

Table 9. Between-Sector Inequality of Gunungkidul County

\begin{tabular}{|l|r|r|r|r|r|}
\hline \multicolumn{1}{|c|}{ Sector } & Agriculture & Trade & Industry & Services & Construction \\
\hline Agriculture & 0.000 & 0.106 & 0.097 & 0.094 & 0.642 \\
\hline Trade & 0.106 & 0.000 & 0.062 & 0.259 & 0.311 \\
\hline Industry & 0.097 & 0.062 & 0.000 & 0.158 & 0.194 \\
\hline Services & 0.094 & 0.259 & 0.408 & 0.000 & 0.018 \\
\hline Construction & 0.642 & 0.311 & 0.194 & 0.018 & 0.000 \\
\hline
\end{tabular}

Inequality in Gunungkidul Regency can be described through the Between-Sector Inequality approach. The agricultural sector with the lowest GRDP per capita has a high inequality if it is compared to the construction sector with a Theil Index of 0.642. Beside the Between-Sector Agriculture and Construction, the income distribution is equally distributed in Gunungkidul although it is at a low level. Therefore, poverty is spread evenly in almost all sectors. Poverty and inequality in Gunungkidul are related to natural geographical conditions that are prone to disasters such as drought. In addition, according to Subejo et al (2019), narrow and dry land ownership cause a lot of urbanization, so that the workers in agricultural sector and other primary sectors migrate to the construction sector.

Table 10. Within-Sector Inequality of Kulon Progo County

\begin{tabular}{|l|r|r|r|r|}
\hline \multicolumn{1}{|c|}{ Sector } & \multicolumn{1}{c|}{ GRDP } & \multicolumn{1}{c|}{ Labor } & \multicolumn{1}{c|}{ per capita } & Theil Index \\
\hline Agriculture & $1,217,211,410,000$ & 178,863 & $6,805,272$ & 0.468 \\
\hline Trade & $1,100,214,210,000$ & 58.715 & $18,738,173$ & 0.668 \\
\hline Industry & 1.015 .724 .150 .000 & 45,413 & $22,366.354$ & 0.645 \\
\hline Services & $1,810,701,750,000$ & 40,943 & $44,224,667$ & 0.642 \\
\hline Construction & $1,990,235,920,000$ & 15,054 & $132,204,306$ & 0.157 \\
\hline
\end{tabular}

In Kulon Progo, Theil Index for Within-Region Inequality has a value of 0.688 or the second highest in the region (Table 4). Within-Sector Inequality proved that the trade sector has the highest income distribution inequality with a value of 0.668 . According to Baniadi \& Mustofa (2018), the trade sector in Yogyakarta has a heterogeneous workers structure. Therefore, the distribution of income becomes very unequal from low income as a peddler to a big trader in tourism centers. In addition, similar conditions occurred in the industrial sector (0.645) and the service sector (0.642). This inequality occurs because Kulon Progo is a buffer zone for the City of Yogyakarta with the highest industrial and service growth [16]. The other reason is because of the new Yogyakarta International Airport that can be a new economic growth catalysator. 
Table 11. Between-Sector Inequality of Kulon Progo County

\begin{tabular}{|l|r|r|r|r|r|}
\hline \multicolumn{1}{|c|}{ Sector } & Agriculture & Trade & Industry & Services & Construction \\
\hline Agriculture & 0.000 & 0.077 & 0.078 & 0.258 & 0.955 \\
\hline Trade & 0.077 & 0.000 & 0.036 & 0.118 & 0.418 \\
\hline Industry & 0.078 & 0.036 & 0.000 & 0.114 & 0.398 \\
\hline Services & 0.258 & 0.118 & 0.178 & 0.000 & 0.032 \\
\hline Construction & 0.955 & 0.418 & 0.398 & 0.032 & 0.000 \\
\hline
\end{tabular}

It is similar to Within-Sector Inequality analysis; Between-Sector Inequality in Kulon Progo Regency shows relatively similar conditions. The agricultural sector to the construction sector is the highest inequality with 0.955 (table 11). The per capita GRDP of the agricultural sector which is only 6.9 million is very far from the construction sector which has a per capita GRDP of 132 million per year. The construction sector is growing rapidly along with the development of infrastructure and real estate in Kulon Progo.

Table 12. Within-Sector Inequality of Sleman County

\begin{tabular}{|l|c|c|c|r|}
\hline \multicolumn{1}{|c|}{ Sector } & GRDP & Labor & per capita & Theil Index \\
\hline Agriculture & $2,105,980,900,000$ & 29,926 & $70,374,126$ & 0.302 \\
\hline Trade & $2,649,325,500,000$ & 91.577 & $28,929,968$ & 0.431 \\
\hline Industry & $4,455,255,000,000$ & 63.060 & $70,651,383$ & 0.255 \\
\hline Services & $9,028,808,300,000$ & 20.185 & $447,302,864$ & 0.070 \\
\hline Construction & $7,304,461,400,000$ & 52.832 & $138,258,541$ & 0.008 \\
\hline
\end{tabular}

Sleman has an equal income distribution in almost all sectors. In fact, the construction sector tends to be evenly distributed (0.008) with a high GRDP per capita (138 million per year). It can be concluded that construction sector in Sleman is also the central construction sector in Yogyakarta. The number of construction entrepreneurs is as high as the income level. This is relevant when compared to the inequality in the construction sector in other regions. So, the construction sector of Sleman is a growth pole that can take workers from other regions (hinterland). This is also happened in the service sector with a high GRDP per capita of 447 million per year with an inequality of 0.070 .

Table 13. Between-Sector Inequality of Sleman County

\begin{tabular}{|l|r|r|r|r|r|}
\hline \multicolumn{1}{|c|}{ Sector } & Agriculture & Trade & Industry & Services & Construction \\
\hline Agriculture & 0.000 & 0.488 & 0.074 & 0.925 & 0.244 \\
\hline Trade & 0.488 & 0.000 & 0.052 & 1,896 & 0.485 \\
\hline Industry & 0.074 & 0.052 & 0.000 & 0.447 & 0.097 \\
\hline Services & 0.925 & 1,896 & 0.447 & 0.000 & 0.069 \\
\hline Construction & 0.244 & 0.485 & 0.097 & 0.069 & 0.000 \\
\hline
\end{tabular}

Between-Sector Inequality Sleman describes the income distribution with an extreme inequality. This is especially happened in the agricultural sector with the service sector and the trade sector with the service sector. The service sector is the leading sector because of the existence of several educational institutions, tourism, and private services. The service sector contributes to extreme inequality in the agricultural and trade sectors. The agricultural sector with a sloping growth pattern is left behind by the service sector. Meanwhile, the trade sector is dominated by small traders at the growth pole of the tourism sector. The rest, income distribution is relatively equal in the trade, industry, services, and construction sectors. 
Table 14. Within-Sector Inequality of Bantul County

\begin{tabular}{|l|r|r|r|r|}
\hline \multicolumn{1}{|c|}{ Sector } & \multicolumn{1}{c|}{ GRDP } & \multicolumn{1}{c|}{ Labor } & per capita & Theil Index \\
\hline Agriculture & $2,075,624.110,000$ & 94,864 & $21,879,968$ & 0.507 \\
\hline Trade & $1,647,733,170,000$ & 116,689 & $14,120,714$ & 0.585 \\
\hline Industry & $2,848,518,050,000$ & 126,424 & $22,531,554$ & 0.442 \\
\hline Services & $4,140,816,440,000$ & 104,785 & $39,517,428$ & 0.270 \\
\hline Construction & $3,191,150,580,000$ & 37,266 & $85,632,336$ & 0.079 \\
\hline
\end{tabular}

Bantul is the area with the highest inequality in Yogyakarta with a Theil Index value of 0.737 (Table 4). Within-Sector Inequality in Bantul shows a tendency of inequality in the agricultural and trade sectors with a Theil Index value more than 0.50 . The agricultural sector in Bantul is the agricultural sector with the most potential and it is a regional food barn at the provincial level. However, the income distribution in the agricultural sector tends to be unequal due to the differences of location, geographical conditions, and land ownership structure. Moreover, geographical conditions in some parts of Bantul have a low rainfall and low soil fertility $[17,18]$. Besides, there is a fertile agricultural sector that produces good food production. This is the reason of inequality. Therefore, in the trade sector, Bantul has a lot of tourism potential starting from mountainous areas and coastal areas. The trade sector is heterogeneous, so that it causes an inequality in income distribution.

Table 15. Between-Sector Inequality of Bantul County

\begin{tabular}{|l|r|r|r|r|r|}
\hline Sector & Agriculture & Trade & Industry & Services & Construction \\
\hline Agriculture & 0.000 & 0.100 & 0.025 & 0.125 & 0.900 \\
\hline Trade & 0.100 & 0.000 & 0.024 & 0.258 & 0.401 \\
\hline Industry & 0.025 & 0.024 & 0.000 & 0.066 & 0.043 \\
\hline Services & 0.125 & 0.258 & 0.235 & 0.000 & 0.012 \\
\hline Construction & 0.900 & 0.401 & 0.043 & 0.012 & 0.000 \\
\hline
\end{tabular}

Table 15 describes information about the highest Between-Sector Inequality in Bantul. It occurs in agricultural sector and construction sector. Inequality in the agricultural sector with a low GRDP per capita also contributes to inequality in the construction sector. The agricultural sector and the construction sector experienced inequality with a Theil Index value of 0.900 (close to 1). The rest, the trade, industry, services, and construction sectors have a relatively equal income distribution.

\section{Conclusion \& Recommendation}

\subsection{Conclusion}

Yogyakarta is still noted as the province with the highest inequality in Indonesia. It had a Gini ratio of 0.437 in 2020 . The inequality issues in the year were influenced by a high poverty level, which was $12.28 \%$.

At the provincial level, we use the Theil analysis with two approximates, i.e., between and within, in which we acquire the figure of 0.686 for within-region inequality in Yogyakarta. Bantul is the district/city with the highest inequality (0.737). Moreover, other areas come with a Theil index of above 0.5 , and accordingly, are considered severely unequal. As regards within-sector inequality in Yogyakarta, we find the highest inequality in the trade sector at a Theil index of 0.988 (close to 1).

Attributed to between-region inequality in Yogyakarta, the most severe inequality is apparent between Kulon Progo and Sleman at a Theil index of 0.703. This inequality occurs on account of significant differences in between-sector GRDP per capita. Concerning 
between-sector inequality in Yogyakarta, severe inequality is identified between the construction sector and other sectors. To the industrial and agricultural sectors, the construction sector has Theil indexes of 0.666 and 0.615 , respectively.

At district/city levels, Gunungkidul has the highest within-sector inequality in the trade (0.640) and service sectors (0.599). Germane to between-sector inequality in the district, the highest inequality is identified between the agricultural sector and the construction sector at 0.641 . Furthermore, Kulon Progo has the highest within-sector inequality in the trade sector (0.688), the industrial sector (0.645), and the service sector (0.642). In light of between-sector inequality in Kulon Progo, inequality is found between the agricultural sector and construction sector at 0.955 .

Sleman has the highest Within-Sector Inequality in the trade sector with a Theil Index of 0.431 . Inequality in Sleman Regency is relatively low because it is less than 0.5 and even close to 0 , namely the construction sector $(0.008)$. In the Bertween-Sector Inequality analysis, Sleman has a moderate inequality between the trade sector and the construction sector with a Theil Index of 0.485 . Meanwhile in Bantul, the sector with the highest inequality is the trade sector $(0.585)$, followed by the agricultural sector $(0.507)$. The highest Between-Sector Inequality in Bantul is Theil Index 0.900 which is the inequality between the agricultural sector and the construction sector.

\subsection{Recommendation}

The high inequality in Yogyakarta occurs in all Districts of the City. Even at the districtcity level, inequality also occurs in almost all sectors. However, the agricultural sector, the trade sector, and the industrial sector are priorities because of the highest inequality (based on within and between approaches).

a. Social security to reduce the impact of poverty and inequality. Subsidies and transfer payments are well targeted to reduce the purchasing power crisis at the household level.

b. The primary sector (agriculture, industry and trade) needs to receive intensive and extensive policy incentives. Intensive on individual workers and extensive on sectoral networks and business climate.

c. The agricultural sector needs to be seriously managed as a place to rely on 40 percent of the workers and population. The increasing of productivity in agricultural sector is through the development of production technology, improvement of input institutions (seeds and fertilizers), and also the efficiency of the trade system.

d. The trade sector needs a policy intervention in the form of price stability, a good business climate, structuring and improving infrastructure and institutions that ensure a perfectly competitive market.

e. Policies to ensure that the small industrial sector has sufficient access to the capital, business capacity development, and production. The improvement of workers and its system to provide decent living needs for workers.

\section{References}

1. Okun, Arthur M. 2015. Equality and Efficiency: The Big Tradeoff. Washington D.C: A Brookings Classic

2. D’Hombres, B; Weber, A; \& Elia, L. 2012. Literature Review on Income Inequality and the Effects on Social Outcomes. Ispra-Italy: European Commission "JRC Scientific and Policy Reports" 
3. Central Bureau of Statistic. 2021. PDB Seri 2010 menurut Lapangan Usaha Tahun 2020. Accessed on April 25 2021 by https://www.bps.go.id/indicator/11/65/1/-seri2010-pdb-seri-2010.html

4. Credit Suisse. 2018. Global Wealth Report 2018. Washington D.C: Research Institute of Credit Suisse

5. Wimmer, Stefan \& Sauer, Johannes. 2020. Profitability Development and Resource Reallocation: The Case of Sugar Beet Farming in Germany. Journal of Agricultural Economics Vol. 71 No. 3 pg. 816-837

6. BAPPEDA DIY. 2020. LKPJ Gubernur DIY 2020. Yogyakart: Badan Perencanaan Pembangunan Daerah

7. Triantafyllou, A; Dotsis, G; \& Sarris, A. 2020. Assessing the Vulnerability to Price Spikes in Agricultural Commodity Markets. Journal of Agricultural Economics Vol. 71 No. 3 pg. 631-651

8. Lopez, A.I \& Ezcaray, H.R. 2020. Labels for a Local Food Speciality Product: The Case of Saffron. Evidence from Canada. Journal of Agricultural Economics Vol. 71 No. 3 pg. 778-797

9. Marcantino, F.D; Ciaian, P; \& Falkowski, J. 2020. Contracting and Farmers' Perception of Unfair Trading Practices in the EU Diary Sector. Journal of Agricultural Economics Vol. 71 No. 3 pg. 877-903

10. Tarigan, H \& Suhaeti R.N. 2018. Karakteristik Komersial dan Perubahan Sosial Petani Kecil. Forum Penelitian Agro Ekonomi Vol. 36 No. 2 hal. 129-144

11. Rozaki, Z.; Salassa, D.I.; Nugroho, R.B. Farmers' responses to organic rice farming in Indonesia: Findings from central Java and south Sulawesi. Open Agric. 2020, 5, 703710, doi:10.1515/opag-2020-0070.

12. Saptana et al. 2018. Dinamika Kelembagaan Kemitraan Usaha Rantai Pasok Buah Tropika Berorientasi Ekspor. Forum Penelitian Agro Ekonomi Vol. 36 No. 2 hal. 45-61

13. Susanawati; Akhmadi, H.; Fauzan, M.; Rozaki, Z. Supply chain efficiency of red chili based on the performance measurement system in Yogyakarta, Indonesia. Open Agric. 2021, 6, 202-211, doi:10.1515/opag-2021-0224.

14. Biewen, Martin \& Flachaire, Emmanuel. 2018. Econometrics and Income Inequality. Basel-Switzerland: MDPI

15. Haughton, Jonathan \& Khander, Shahidur R. 2009. Handbook on Poverty + Inequality. Washington D.C: The World Bank

16. Rozaki, Z.; Wijaya, O.; Wardana, C.K. Agriculture developement based on regional potency in kulonprogro regency. IOP Conf. Ser. Earth Environ. Sci. 2021, 683, doi:10.1088/1755-1315/683/1/012091.

17. Subejo et al. 2019. Modernization of Agriculture and Use of Information and Communication Technologies by Farmers in Coastal Yogyakarta. Indonesian Journal of Geography Vol. 51 No. 3

18. Winarno, B. Neoliberal Policy of Indonesia's Agricultural Revitalization. Jurnal Hubungan Internasional. 2016, 5, 31-39, doi:10.18196/HI.2016.0083.30-39. 